\title{
METODY UWZGLECDNIANIA IMPERFEKCJI GEOMETRYCZNYCH W KRATOWNICACH STALOWYCH
}

\begin{abstract}
Aktualne wytyczne normowe oraz badania zalecają aby przy projektowaniu złożonych układów konstrukcyjnych, szczególnie układów ramowych, uwzględniać wpływ imperfekcji geometrycznych. W przypadku kratownicy imperfekcje mogą występować niezależnie w każdym pręcie co prowadzi do dużej różnorodności możliwych konfiguracji imperfect. W niniejszej pracy przedstawiono, znane $\mathrm{z}$ analizy ram, metody uwzględniania imperfekcji geometrycznych oraz możliwości ich zastosowania w przypadku kratownic. Wykonano obszerną analizę numeryczną pewnego modelu kratownicy $\mathrm{w}$ celu porównania przedstawionych metod oraz wpływu jednocześnie występujących poprzecznych imperfekcji geometrycznych obu pasów na nośność kratownicy. Rozpatrywano imperfekcje łukowe na długości całego pasa jak również pomiędzy punktami jego sztywnego podparcia bocznego. Na podstawie otrzymanych wyników opracowano ścieżki równowagi ściskanego pasa kratownicy. Opisane i wykorzystane, w analizie numerycznej, metody uwzględniania imperfekcij oceniono pod względem pracochłonności i możliwości ich stosowania w układach kratowych.
\end{abstract}

Słowa kluczowe: model imperfect; kratownice; analiza; obciążenie graniczne

\section{Wstęp}

W trakcie projektowania konstrukcji stalowych zaleca się uwzględniać występujące w nich wstępne imperfekcje geometryczne globalne i lokalne. Informacje na ten temat można znaleźć w wielu normach, m.in. w EC3; BS 5950; GB 50017 oraz AISC 360-05. Normy te, oraz dostępna literatura, omawiają głównie wpływ imperfekcji na układy ramowe o elementach pełnościennych. W takich układach uwzględnia się głównie globalne imperfekcje przechyłowe występujące w płaszczyźnie układu poprzecznego a ich maksymalna wartość jest przyjmowana wg analizy deterministycznej lub probabilistycznej [1], [8].

W kraju prowadzono obszerne badania numeryczne i doświadczalne, dotyczące dźwigarów kratowych, skupiając się na określeniu właściwej długości wyboczeniowej ściskanych pasów kratownic z poprzecznym, sztywnym lub sprężystym, podparciem pośrednim [7], [9]. Niewiele jest natomiast publikacji dotyczą-

\footnotetext{
${ }^{1}$ Michał Piątkowski, Politechnika Koszalińska, Zakład Konstrukcji Metalowych, ul. Śniadeckich 2, 75-453 Koszalin; tel. 606761760; michal.piatkowski@tu.koszalin.pl
} 
cych wpływu imperfekcji geometrycznych na nośność i stateczność kratownic. W większości są to publikacje "post factum" dotyczące błędów montażowych i awarii istniejących już konstrukcji [10], [15].

Duży wpływ na nośność ustroju kratowego mają poprzeczne imperfekcje geometryczne. Imperfekcje te mogą wystąpić jednocześnie w pasach oraz w skratowaniu. Mogą one wynikać z niedokładnego wykonania elementu lub z błędnego montażu. Ponadto mogą one być niezależne od siebie co prowadzi do dużej liczby możliwych geometrii imperfect analizowanej kratownicy. Wnioski te skłoniły autora do podjęcia tematu dotyczącego wpływu wstępnych imperfekcji geometrycznych „z płaszczyzny układu” na nośność i stateczność kratownic.

\section{Rodzaje imperfekcji oraz metody ich uwzględniania}

Analizując ramowe układy konstrukcyjne należy zwrócić uwagę na normowy podział imperfekcji geometrycznych na globalne, np. przechyłowe całej ramy (rys. 1. a) oraz lokalne łukowe pojedynczych elementów (rys. 1. b) [11]. Podział ten jest niewystarczający w przypadku kratownic. Wprowadzono dodatkowy podział imperfekcji pasów na łukowe imperfekcje globalne na długości całego pasa kratownicy (rys. 2. a $\div$ c) oraz łukowe imperfekcje lokalne (rys. 2. d), występujące pomiędzy punktami bocznego podparcia pasa lub pomiędzy węzłami. Ponadto w kratownicach można wyróżnić imperfekcję łamaną pasa, jeżeli występuje w nim styk montażowy (rys. 2. e) oraz imperfekcję przechyłową całej kratownicy występującą w układzie ramowym złożonym z kratownic połączonych płatwiami i poszyciem dachowym (rys. 2. f).

W przypadku konstrukcji złożonej z wielu elementów, takiej jak kratownica, układ imperfekcji w poszczególnych elementach składowych jest w dużej mierze losowy. Może to prowadzić zarówno do ich wzajemnego znoszenia się, jak i wzmacniania. Jeżeli układ imperfekcji będzie maksymalnie niekorzystny, to taki element może zostać przeciążony oraz ulec awarii. Dlatego, między innymi, uwzględnianie imperfekcji w konstrukcjach złożonych jest istotne już na etapie analizy statycznej.

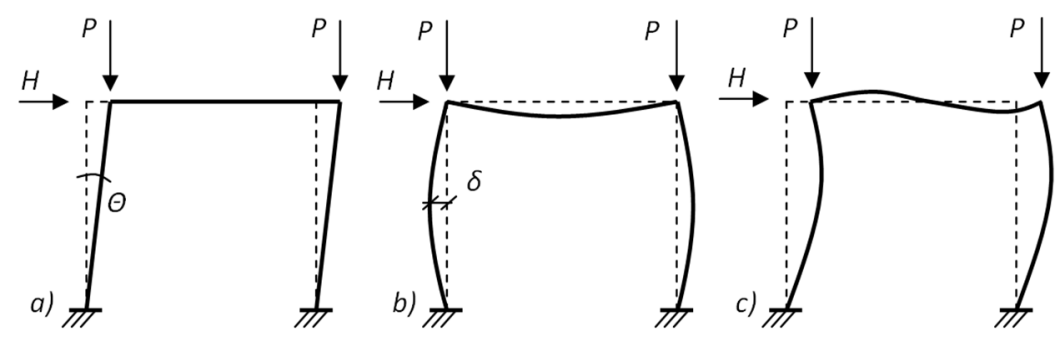

Rys. 1. Rodzaje imperfekcji w układach ramowych pełnościennych: a) imperfekcja globalna przechyłowa; b) imperfekcje lokalne łukowe; c) jednoczesne imperfekcje przechyłowa i łukowe

Fig. 1. Types of imperfection in frames system: a) sway global imperfection; b) local out-ofstraightness imperfection; c) simultaneous sway and out-of-straightness imperfections 


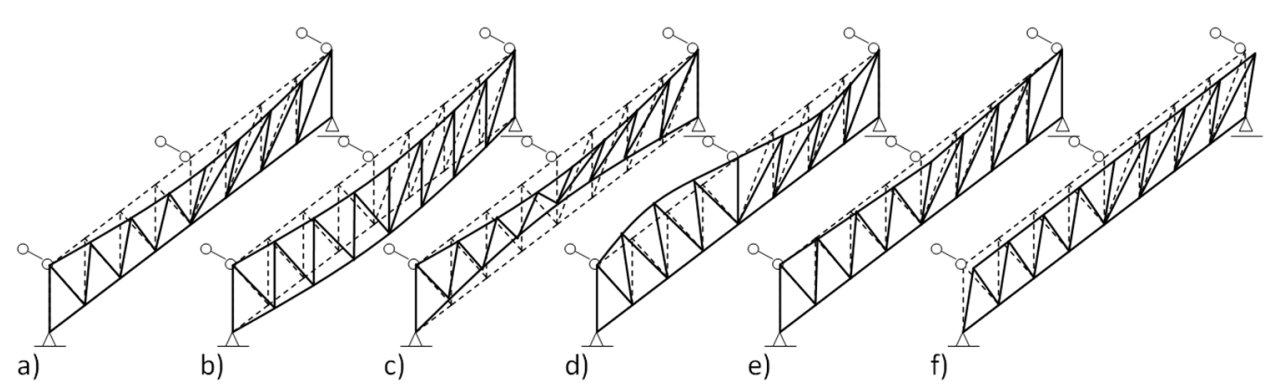

Rys. 2. Rodzaje imperfekcji "z płaszczyzny układu" w kratownicach (opis w tekście)

Fig. 2. Types of imperfection "out of plane" in a truss (description in the text)

Istnieje wiele metod uwzględniania imperfekcji geometrycznych w obliczeniach statycznych konstrukcji. Metody te zostały wymienione i szeroko opisane m.in. w pracach [5], [6] i [14]. Główne z nich to:

- bezpośrednie modelowanie wstępnych imperfekcji geometrycznych (modeling of Initial Geometric Imperfections - IGI),

- skalowanie pierwszej postaci utraty stateczności jako układu imperfect (scaling of first EigenBuckling Mode - EBM),

- stosowanie zastępczych obciążeń równoważnych (application of Notional Horizontal Forces - NHF),

- redukcja modułu sprężystości modelu perfect (reduction of member stiffness $\left.\mathbf{E}_{\text {red }}\right)$.

Obowiązujący obecnie w Polsce Eurokod 3 zaleca uwzględnianie imperfekcji globalnych poprzez stosowanie metody NHF przy wykorzystaniu analizy I, jak i II rzędu [11]. Natomiast imperfekcje lokalne można uwzględniać w zależności od metody analizy:

- w przypadku analizy I rzędu - poprzez formuły sprawdzania nośności elementów narażonych na wyboczenie.

- w przypadku analizy II rzędu - poprzez formuły sprawdzania nośności przekrojów. Imperfekcje lokalne należy wtedy uwzględnić za pomocą normowej metody NHF.

\section{Analiza numeryczna}

W celu oceny przedstawionych metod pod kątem ich przydatności dla układów kratowych wykonano obszerne analizy numeryczne. W analizach uwzględniono model kratownicy przedstawionej na rys. 3. Kratownice o takim schemacie były użyte w badaniach doświadczalnych szerzej opisanych w pracy [13].

Wykorzystując oprogramowanie SOFISTIK opracowano prętowy model kratownicy w układzie przestrzennym. Przyjęto sztywne połączenie wykratowania z pasami. Uwzględniano, wzrastające skokowo, grawitacyjne obciążenie śledzące przyłożone do węzłów pasa górnego. Na każdym poziomie obciążenia, przy wy- 


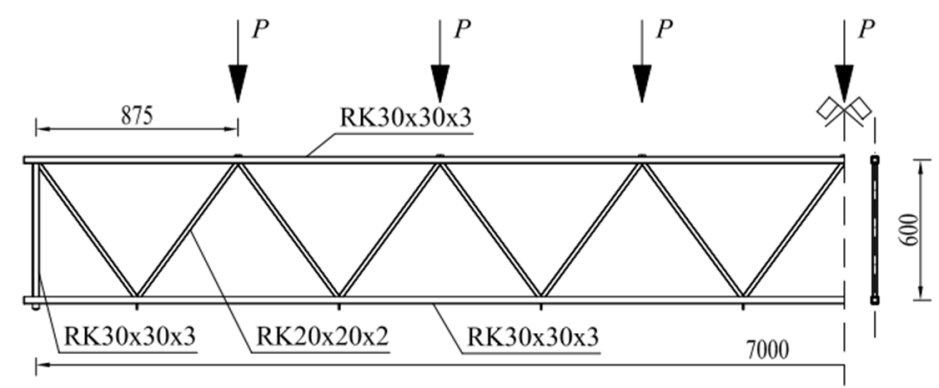

Rys. 3. Schemat analizowanej kratownicy

Fig. 3. Scheme of the analyzed truss

korzystaniu analizy geometrycznie nieliniowej określano maksymalne przemieszczenia poziome pasów kratownicy. W analizach przyjęto parametry stali S235 o nominalnej wartości modułu sprężystości $E=210 \mathrm{GPa}$. Uwzględniono trzy możliwe układy parabolicznych imperfekcji globalnych (IMP $1 \div 3$ ) i lokalnych (IMP LOK $1 \div 3$ ) oraz trzy modele sztywnego podparcia bocznego kratownicy (Model 1 $\div 3$ ). Przedstawia to rys.4.

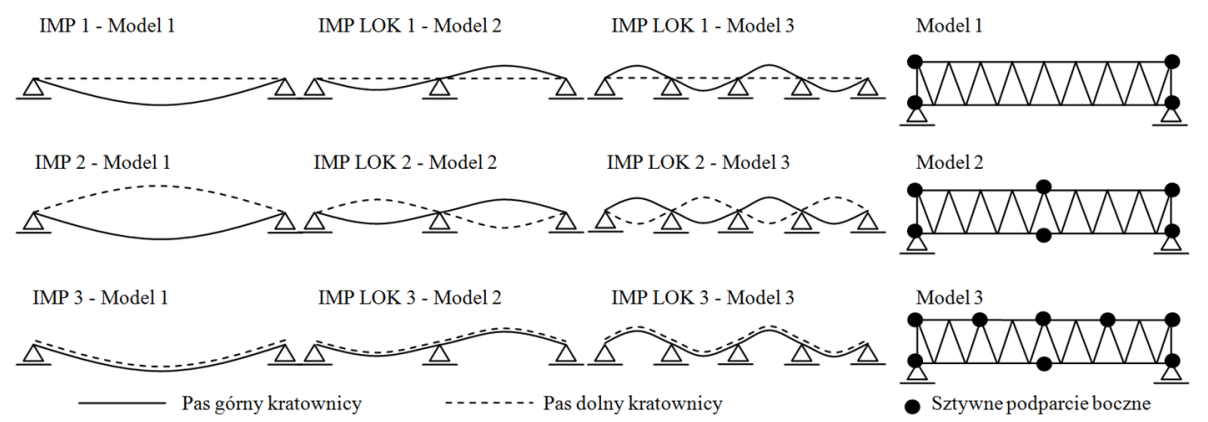

Rys. 4. Przyjęte układy imperfekcji oraz modele podparcia bocznego pasów kratownicy

Fig. 4. Adopted configuration of imperfections and models of lateral support of the chords

\subsection{Metoda IGI - deterministyczna}

Znając dopuszczalne odchyłki montażowe i wykonawcze zawarte w [12] można określić dopuszczalną konfigurację imperfect konstrukcji. W układach złożonych istnieje wiele takich konfiguracji. Jednoznaczne wybranie konfiguracji najbardziej niekorzystnej jest więc trudne i wymaga wielokrotnej modyfikacji geometrii początkowej układu oraz wielokrotnych obliczeń numerycznych. W prezentowanej analizie określono dopuszczalne łukowe imperfekcje pasów zgodnie z normami [11] i [12], następnie zmodyfikowano współrzędne węzłów w modelu tak, aby odpowiadał on przyjętym układom imperfekcji. 

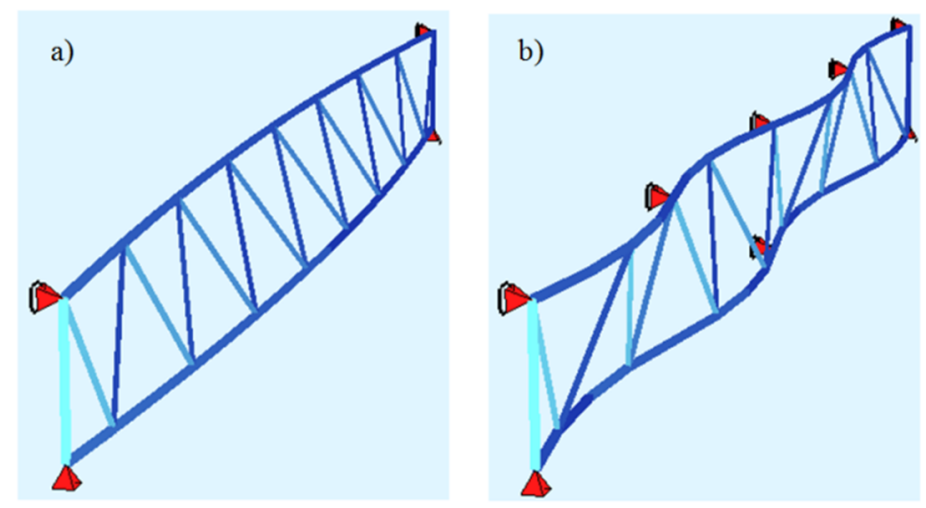

Rys. 5. Przykładowe konfiguracje imperfect kratownicy (deformacje powiększone 10-krotnie): a) IMP 2 - Model 1; b) IMP LOK 2 - Model 3

Fig. 5. Examples of imperfect configuration of the truss (deformations enlarged 10 times): a) IMP 2 - Model 1; b) IMP LOK 2 - Model 3

\subsection{Metoda IGI - probabilistyczna}

W polskiej literaturze $\mathrm{z}$ ostatnich lat mało jest informacji na temat badań statystycznych dotyczących rzeczywistych imperfekcji geometrycznych wykonywanych obecnie konstrukcji. Zagraniczne badania w tym temacie opisywane były częściej, m. in. w pracy [14].

Jeżeli założymy, że wartość imperfekcji geometrycznych nie przekracza wartości dopuszczalnych, może przyjmować wartości zarówno dodatnie, jak i ujemne oraz że jest równie prawdopodobna w całym swoim przedziale, to można wybrać pewną próbę losową będącą odzwierciedleniem całej populacji [3]. W prezentowanej analizie założono, że:

- imperfekcje mogą przyjmować wartości dodatnie i ujemne,

- kształt wstępnej imperfekcji pasa jest opisany funkcją $f(x)$ (wzór 1)

- wartości jej kolejnych amplitud $e_{i}$ są wartościami losowymi, które nie przekraczają wartości dopuszczalnych.

Następnie wylosowano dziesięć zestawów wartości $e_{1}$ oraz $e_{i}$ (poszczególne układy imperfekcji pasów oznaczono P1 - P10) dla każdego pasa. Pozwoliło to określić jego losową geometrię imperfect za pomocą funkcji:

$$
f(x)=e_{1} \sin \left(\frac{x \cdot \pi}{L}\right)+e_{i} \sin \left(\frac{x \cdot 2 \pi}{L}\right)+e_{i} \sin \left(\frac{x \cdot 4 \pi}{L}\right)+e_{i} \sin \left(\frac{x \cdot 8 \pi}{L}\right)
$$

gdzie: $\quad e_{1}$-amplituda łukowej imperfekcji globalnej, $e_{1 \cdot \max }= \pm L / 500$,

$L$ - długość całkowita kratownicy,

$e_{i}$ - amplituda łukowej imperfekcji lokalnej, $e_{i, \max }= \pm L_{i} / 200, i=2,3,4$,

$L_{i}$ - długość pasa pomiędzy stężeniami lub pomiędzy węzłami. 


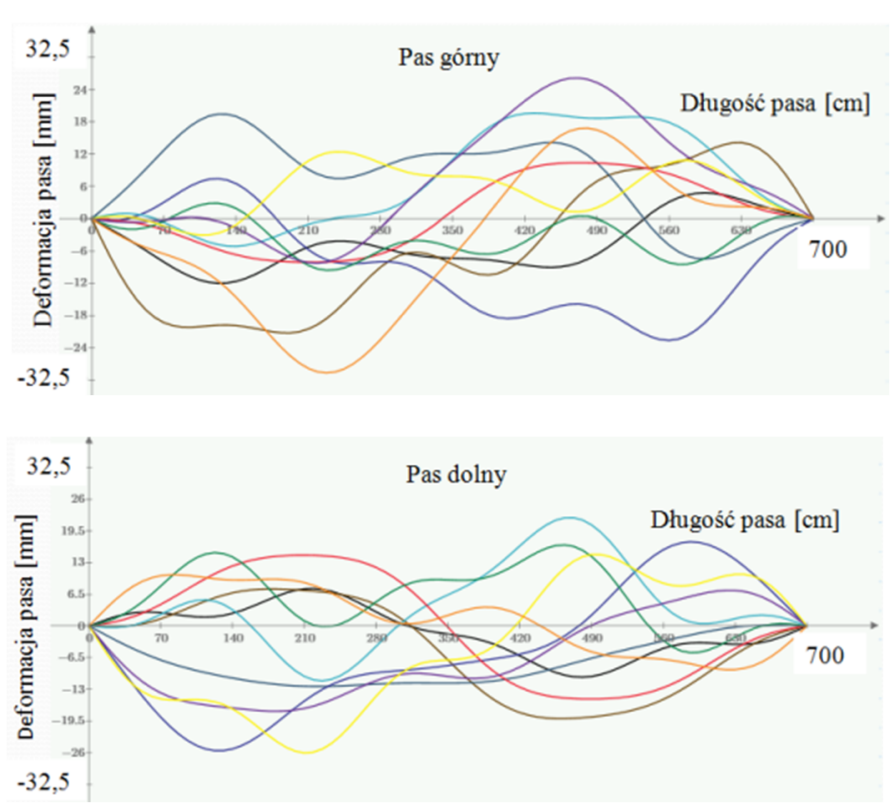

Rys. 6. Losowe imperfekcje pasów

Fig. 6. Random imperfections of the chord

\subsection{Metoda EBM}

Skalowanie pierwszej postaci utraty stateczności jako układu imperfect jest szczególnym przypadkiem deterministycznego wariantu metody IGI. Metoda ta zakłada, że najbardziej niekorzystnym układem wstępnych imperfekcji w całej konstrukcji jest układ zgodny z kształtem jej pierwszej postaci utraty stateczności. Zasada ta nie jest słuszna w przypadku konstrukcji przesztywnionych, w których
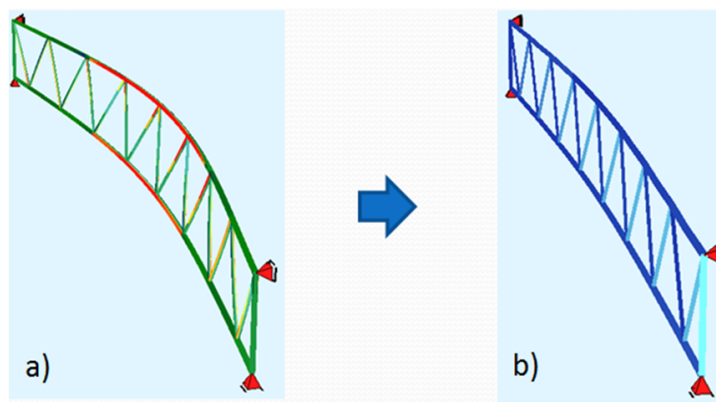

Rys. 7. Stosowanie metody EBM: a) pierwsza postać utraty stateczności kratownicy; b) konfiguracja imperfect

Fig. 7. Principles of the EBM method application: a) first buckling mode of truss; b) imperfect configuration przed utratą stateczności dochodzi do wyczerpania nośności plastycznej przekroju i zmiany pierwotnej konfiguracji geometrycznej. W prezentowanej analizie dla każdego modelu podparcia bocznego kratownicy wykonano sprężystą analizę wyboczeniową w celu określenia siły krytycznej oraz odpowiedniej postaci utraty stateczności. Następnie odpowiednio wyskalowaną konfigurację imperfect uwzględniono w modelu numerycznym. 


\subsection{Metoda NHF}

Geometryczne imperfekcje są $\mathrm{w}$ tej metodzie zastępowane równoważnym obciążeniem poprzecznym przyłożonym do konstrukcji o konfiguracji perfect. Wartość tego obciążenia zależy od siły ściskającej w elemencie i wraz z nią powodują takie same deformacje jak w przypadku ściskanego pręta imperfect. Przyłożone do elementu obciążenie zastępcze musi być samo zrównoważone tak aby nie powodować dodatkowego wytężenia $w$ innych, sąsiednich elementach [2]. W prezentowanej analizie kratownicy wprowadzono dodatkowe obciążenia zastępcze $q_{1}$ oraz $q_{2}$ przyłożone do układu perfect (rys. 8.b). Wartość tych obciążeń została dobrana w taki sposób, aby przy obciążeniu $P=0$ uzyskać deformację odpowiadającą właściwym układom imperfekcji przyjętym w metodzie IGI.
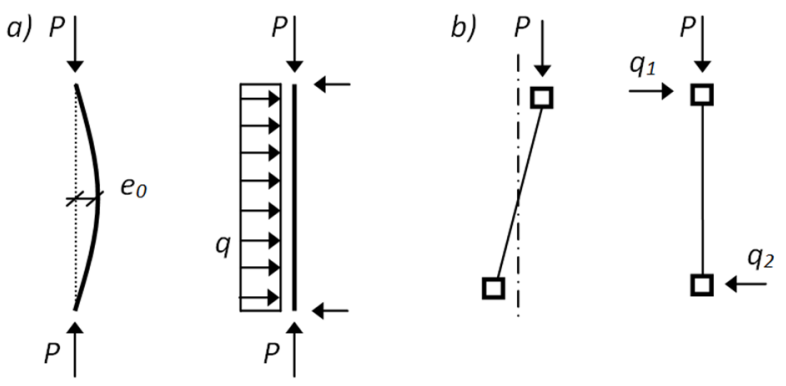

Rys. 8. Schemat metody NHF: a) pojedynczy pręt; b) kratownica

Fig. 8. Scheme of the NHF method: a) single element; $b$ ) truss

\subsection{Metoda Ered}

Metoda ta polega na celowym obniżeniu stycznego modułu sprężystości $E_{t}$ elementu. Pozwala ona uwzględnić wpływ imperfekcji geometrycznych na zachowanie się elementu bez konieczności wprowadzania do analiz numerycznych konfiguracji imperfect lub obciążeń zastępczych (rys. 9.). Zredukowany moduł sprężystości $E_{t}^{*}$ określa się na podstawie zależności (2) i (3) opracowanych zgodnie z zaleceniami amerykańskiego stowarzyszenia Column Research Council (CRC). Na podstawie licznych badań i analiz, w przypadku konstrukcji ramowych stężonych oraz niestężonych, współczynnik redukcyjny $\xi$ określono na poziomie 0,85 [4].

$$
\begin{aligned}
& {E_{t}{ }^{*}}^{=} \xi \cdot E \Rightarrow P \leq 0,5 P_{y} \\
& E_{t}{ }^{*}=4 \cdot \frac{P}{P_{y}} \cdot\left(1-\frac{P}{P_{y}}\right) \cdot \xi \cdot E \Rightarrow P>0,5 P_{y}
\end{aligned}
$$

gdzie: $\quad \xi$-współczynnik redukcyjny o wartości równej 0,85 ,

$E$ - moduł sprężystości stali,

$P$ - obciążenie zewnętrzne,

$P_{y}-$ nośność plastyczna przekroju elementu. 
Metoda $\mathbf{E}_{\text {red }}$ stosowana do określenia wpływu imperfekcji "z płaszczyzny" na nośność kratownicy ma zastosowanie tylko w przypadku występowania dodatkowego obciążenia poprzecznego $H$. Obciążenie takie, np. wiatrem ściany szczytowej, powoduje powstanie przemieszczeń poprzecznych, które w układzie perfect o zredukowanym module sprężystości mają porównywalną wartość $\mathrm{w}$ stosunku do przemieszczeń układu imperfect o sztywności nominalnej. W przedstawianej analizie przyjęto różne wartości współczynników redukcyjnych $(0,8 ; 0,85 ; 0,9)$ w celu określenia ścieżek równowagi analizowanej konstrukcji kratowej. Przyjęto również pewne obciążenie $H=0,05 P$ przyłożone do węzłów pasa górnego kratownicy, reprezentujące oddziaływanie wiatru na ścianę szczytową.

a)

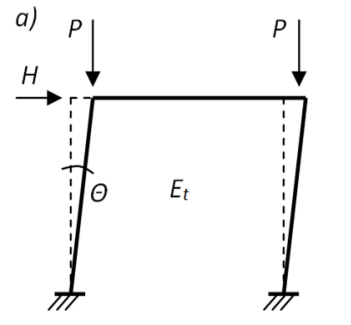

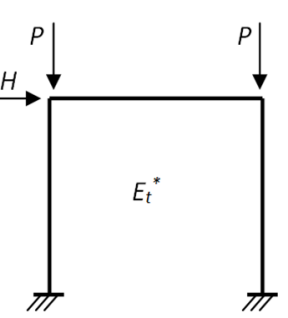

b)

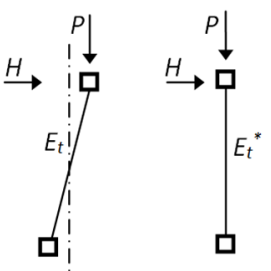

Rys. 9. Zasady zastosowania metody Ered: a) rama parterowa; b) kratownica

Fig. 9. Principles of the Ered method application: a) one-storey frame; b) truss

\section{Wyniki analizy}

Przedstawione wyżej metody wykorzystano do określenia ścieżek równowagi pasa górnego analizowanego modelu kratownicy. Ścieżki te opracowano jako zależność pomiędzy wiodącym, maksymalnym przemieszczeniem poziomym ściskanego pasa kratownicy a węzłowym obciążeniem $P$ kratownicy. Wybrane wyniki przedstawiono na rys. $10 \div 12$. W przypadku metody $\mathbf{E}_{\text {red }}$ opracowano ścieżki równowagi tylko dla modelu 1 . Natomiast w przypadku pozostałych metod zaprezentowane ścieżki równowagi obejmują wszystkie modele podparcia bocznego oraz przyjęte układy imperfekcji. 


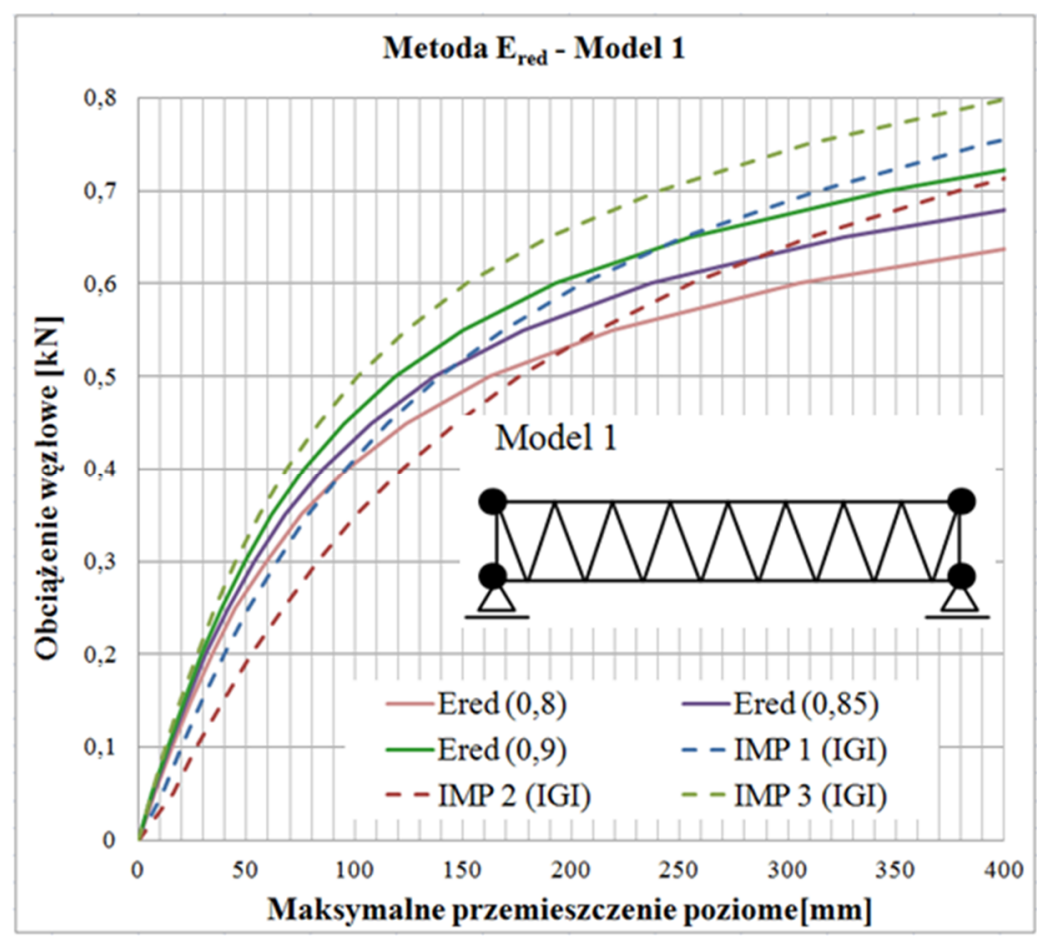

Rys. 10. Ścieżki równowagi pasa górnego kratownicy w metodzie $\mathrm{E}_{\mathrm{red}}$ - model 1

Fig. 10. Equilibrium path of the upper chord of truss, $\mathrm{E}_{\text {red }}$ method - model 1

Prezentowane ścieżki równowagi dążą zawsze do wspólnej asymptoty, która odpowiada obciążeniu krytycznemu ściskanego pasa kratownicy. Z uwagi jednak na różne, przyjęte układy imperfekcji, ścieżki te charakteryzują się różnym spłaszczeniem zależnym od wstępnego skręcenia kratownicy. Można założyć, że zależność pomiędzy obciążeniem kratownicy a maksymalnym wytężeniem przekroju pasa górnego dla przyjętych układów imperfekcji i modeli podparcia jest podobna do prezentowanych ścieżek równowagi [13].

Ścieżki równowagi pasa górnego, uzyskane przy wykorzystaniu probabilistycznej metody IGI oraz metody EBM (rys. 12.), zostały przedstawione razem $\mathrm{z}$ wynikami uzyskanymi w deterministycznym wariancie metody IGI. 

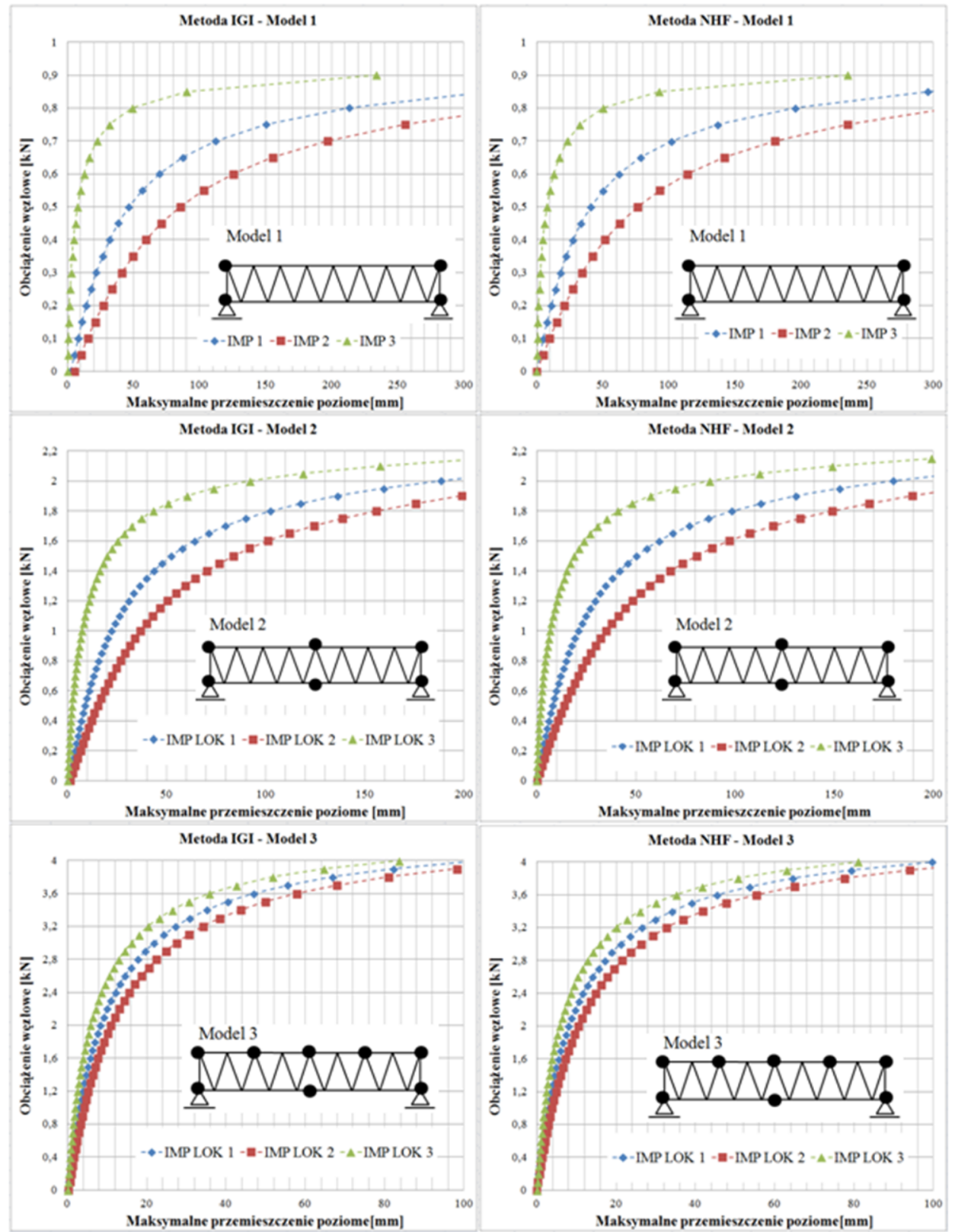

Rys. 11. Ścieżki równowagi pasa górnego kratownicy. Metoda IGI (podejście deterministyczne) oraz metoda NHF

Fig. 11. Equilibrium path of the upper chord of truss. IGI method (deterministic) and NHF method 

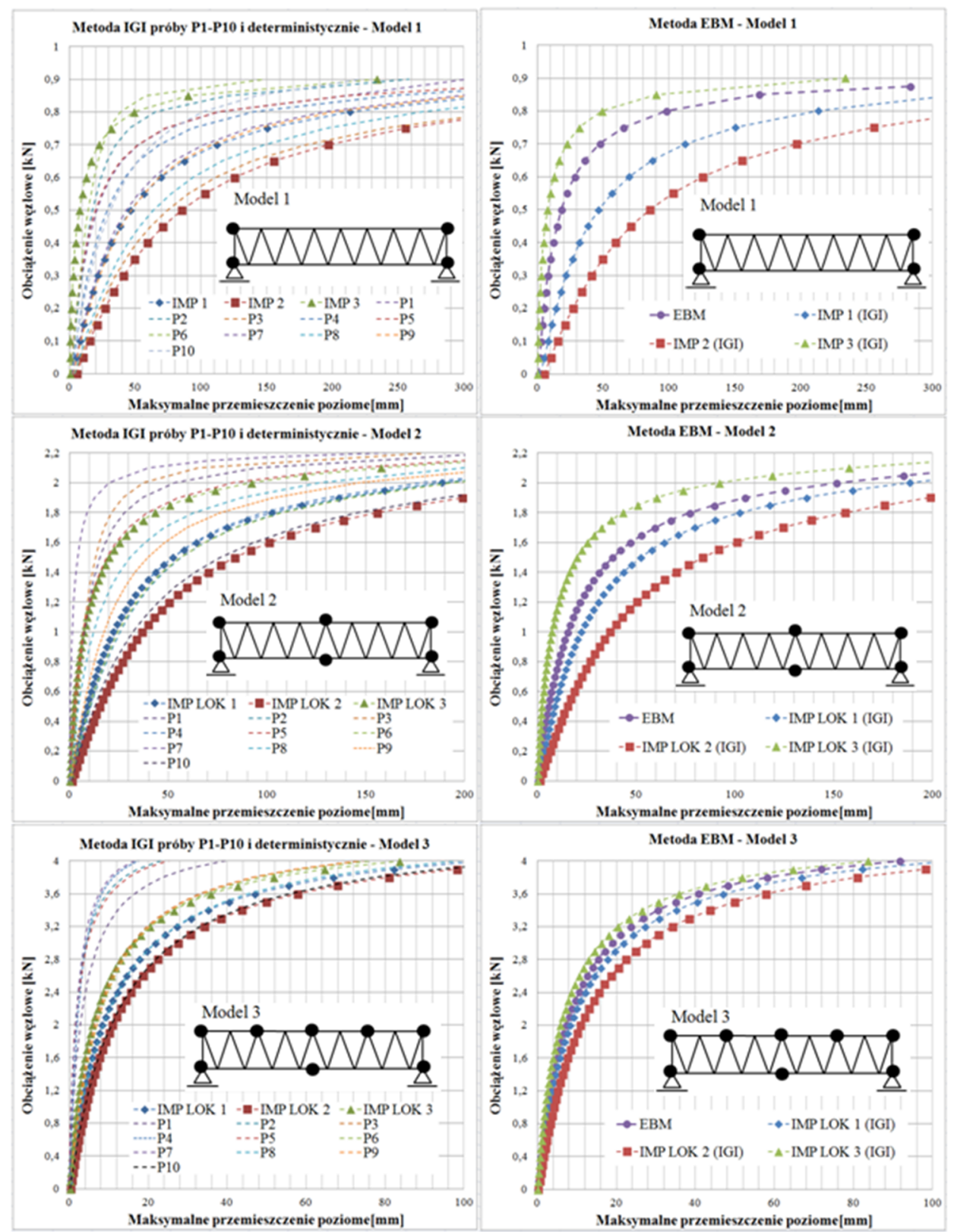

Rys. 12. Ścieżki równowagi pasa górnego kratownicy. Metoda IGI (podejście probabilistyczne) oraz metoda EBM

Fig. 12. Equilibrium path of the upper chord of truss. IGI method (probabilistic) and EBM method 


\section{Podsumowanie}

Porównanie wymienionych na wstępie metod rozpoczęto od ich oceny pod kątem pracochłonności oraz wymagań dotyczących znajomości zasad projektowania i korzystania $\mathrm{z}$ oprogramowania. $\mathrm{W}$ trakcie tworzenia modelu numerycznego wykorzystano tekstowy panel edycyjny programu komputerowego SOFISTIK, który umożliwiał wprowadzanie deformacji elementów przy użyciu funkcji parabolicznej bądź sinusoidalnej o zdefiniowanych wcześniej parametrach, takich jak maksymalne wychylenie. Pozwoliło to znacznie skrócić czas tworzenia modelu numerycznego w konfiguracji imperfect.

Należy stwierdzić, że deterministyczna metoda IGI, wymaga od projektanta najwięcej nakładu pracy i bardzo dobrej znajomości oprogramowania. Jest to spowodowane dużą liczbą możliwych układów imperfect, które każdorazowo należy modelować od początku w celu określenia, który z nich jest układem najbardziej niekorzystnym.

Podobną pod względem pracochłonności metodą, zdaniem autora, jest metoda NHF. Pomimo, iż nie wymaga ona modelowania układu imperfect, to należy w niej odpowiednio dobrać obciążenie zastępcze, które spowoduje właściwą deformację układu. Dodatkowo w celu określenia najbardziej niekorzystnego układu imperfekcji konstrukcji należy wykonać kombinację obciążeń zastępczych oraz projektowych, co znacznie komplikuje proces projektowania.

Następne, podobne do siebie, pod względem pracochłonności metody to probabilistyczna metoda IGI oraz EBM. W obu tych metodach można tylko raz wymodelować, określony wcześniej poprzez próbę losową lub analizę stateczności, układ imperfect. Pozwala to znacznie skrócić cały proces definiowania modelu numerycznego

Najmniej pracochłonną jest metoda $\mathbf{E}_{\text {red }}$ dzięki wykorzystaniu modelu perfect. Metoda ta nie wymaga dodatkowych obciążeń zastępczych oraz wcześniejszego poszukiwania najbardziej niekorzystnego układu imperfekcji.

Ocena ta, mimo iż w dużej mierze subiektywna, jest ważnym czynnikiem określającym przydatność wymienionych metod pod kątem zastosowania w układach kratowych.

Jak wykazały analizy, układ imperfekcji pasów kratownicy ma wpływ na ścieżkę równowagi konstrukcji, zatem również na wytężenie jej poszczególnych elementów. Dlatego też równie ważnym czynnikiem oceny wymienionych metod jest możliwość znalezienia oraz uwzględnienia najbardziej niekorzystnego układu imperfekcji. Jest to możliwe tylko przy zastosowaniu deterministycznej metody IGI oraz metody NHF. Zgodnie z wynikami powyższej analizy oraz wynikami badań doświadczalnych opisanych w pracy [13], za najbardziej niekorzystny układ imperfekcji należy uznać układ IMP 2 (Model 1) oraz IMP LOK 2 (Model 2 i Model 3) czyli układy, w których skręcenie poszczególnych przekrojów kratownicy jest największe. 
Probabilistyczny wariant metody IGI pozwala określić konfigurację pośrednią pomiędzy układem perfect a układem najbardziej niekorzystnym. Warto zauważyć, że w przypadku modelu 1 prawie wszystkie ścieżki równowagi ( $\mathrm{z}$ wyjątkiem próby P6) znajdują się w obszarze wyznaczonym pomiędzy układami IMP 3 oraz IMP 2, otrzymanymi z deterministycznej analizy IGI. W przypadku Modelu 2 i 3 więcej prób losowych znajduje się poza analogicznym obszarem pomiędzy IMP LOK 3 oraz IMP LOK 2. W przypadku modelu 2 są to 4 z 10 prób, natomiast w przypadku modelu 3 jest to aż 8 z 10 prób. Stosowanie metody probabilistycznej musi być oparte o niezbędne prognozy statystyczne dotyczące możliwości wystąpienia imperfekcji w projektowanej konstrukcji.

Zastosowanie metody EBM w przypadku układów kratowych może prowadzić do niedoszacowania wytężenia pasa ściskanego. Jest to spowodowane charakterem utraty stateczności kratownicy płaskiej. Wyskalowana postać utraty stateczności w analizowanych modelach kratownic charakteryzuje się jednostronnym wychyleniem pasa górnego i dolnego oraz niewielkim skręceniem przekroju kratownicy (pas ściskany ciągnie za sobą pas rozciągany, rys.7. a.). Jak wykazały analizy z wykorzystaniem innych metod nie jest to najbardziej niekorzystny układ imperfekcji wobec tego stosowanie metody EBM może być niekorzystne z punktu widzenia bezpieczeństwa konstrukcji.

Podobnie jest w przypadku metody $\mathbf{E}_{\text {red }}$, która wymaga istnienia rzeczywistego obciążenia $H$. Obciążenie takie, np. parcie wiatru na ścianę szczytową powoduje jednostronną deformację pasów. Dlatego też otrzymane ścieżki równowagi (przy współczynnikach redukcyjnych 0,$8 ; 0,85 ; 0,9$ ) znajdują się blisko ścieżki równowagi IMP 3 przy niewielkich wartościach obciążenia $P$. Należy również zaznaczyć, że stosowanie współczynnika redukującego styczny moduł sprężystości $E_{t}$ wpływa na zmniejszenie sztywność całej kratownicy, co prowadzi do zwiększenia przemieszczeń pionowych.

\section{Wnioski}

Przedstawione analizy numeryczne oraz ich podsumowanie pozwalają wyciągnąć kilka wniosków dotyczących uwzględniania imperfekcji geometrycznych w układach kratowych oraz wpływu imperfekcji na nośność tych układów. Wnioski te mogą być pomocne w pracach projektowych oraz wyznaczyć zakres dalszych analiz.

Układ geometrycznych imperfekcji pasów kratownicy wpływa na jej nośność i stateczność. Wpływ ten zwiększa się wraz ze wzrostem skręcenia przekroju kratownicy oraz zmniejszeniem liczby podparć bocznych.

W dostępnej literaturze krajowej brakuje informacji na temat statystycznego rozkładu geometrycznych imperfekcji wykonawczych i montażowych w produkowanych i montowanych obecnie kratownicach. Trudno więc zweryfikować założenia dotyczące kształtu i rozkładu statystycznego losowych imperfekcji w metodzie IGI - probabilistycznej. 
Ścieżki równowagi otrzymane metodami IGI - deterministycznej oraz NHF (rys.11.) pokrywają się we wszystkich analizowanych układach imperfekcji i modelach podparcia bocznego pasów (maksymalna różnica przemieszczeń wynosi 7\%). Zatem metody te można uznać za tożsame i mogą być wykorzystywane zamiennie.

W przypadku kratownic stosowanie metody $\mathbf{E B M}$ oraz $\mathbf{E}_{\text {red }}$ wydaje się nieuzasadnione $\mathrm{z}$ uwagi na pomijanie najbardziej niekorzystnego układu imperfekcji.

Dopuszczalne odchyłki zawarte w normach wykonawczych powinny gwarantować, że rzeczywiste imperfekcje nie wpłyną znacząco na nośność i stateczność konstrukcji. Zawarte w normie [12] odchyłki dotyczące wykonania i montażu kratownic są niewystarczające, ponieważ nie uwzględniają przypadku jednoczesnej, przeciwnej imperfekcji obu pasów. Rozwiązaniem tego problemu było by wprowadzenie odchyłki skrętnej całej kratownicy płaskiej. Odchyłka taka wymuszałaby na wykonawcach konieczność rektyfikacji zamontowanych kratownic i sprowadzenia obu pasów do płaszczyzny pionowej.

W pracy analizowano kratownicę ze smukłymi pasami równoległymi z uwzględnieniem niepodatnych pośrednich stężeń bocznych pasów. Następnym etapem prowadzonych analiz będzie ocena wpływu układu imperfekcji na ścieżkę równowagi kratownicy ze sprężystymi stężeniami bocznymi oraz pasami nierównoległymi o mniejszej smukłości.

\section{Literatura}

[1] Alvarenga Arthur R., Silveria Ricardo A. M.: Second-order plastic-zone analysis of steel frames- part II: effects of initial geometric imperfection and residual stress. Latin Americas Journal of Solid and Structures, 6/2009: 323-342.

[2] Biegus Antoni: Obciążenie imperfekcyjne poziomych stężeń poprzecznych dźwigarów wspornikowych i wieloprzęsłowych. Inżynieria i Budownictwo, 11/201: 578-581.

[3] Biegus Antoni: Probabilistyczna analiza konstrukcji stalowych. Wydawnictwo Naukowe PWN, Warszawa - Wrocław 1999.

[4] Chen Wai-Fah: Structural stability: from theory to practice. Engineering Structures. 22/2000: 116-122.

[5] Chen Wai-Fah, Kim Seung-Eock: LRFD Steel design using advanced analysis. CRC Press, New York 1997.

[6] Chen Wai-Fah, Lui Eric M.: Principles of structural design. Taylor and Francis, 2006.

[7] Jankowska-Sandberg Joanna, Kołodziej Jarosław: Experimental study of steel truss lateral-torsional buckling. Engineering Structures. 46/2013: 165-172.

[8] Kala Zdenek: Sensitivity analysis of steel plane frames with initial imperfections. Engineering Sturctures, 33/2011: 2342-2349.

[9] Krajewski Marcin, Iwicki Piotr: Analysis of brace stiffness influence on stability of the truss. Journal of Applied Mechanics and Engineering, 20(1)/2015: 97-108.

[10] Niewiadomski Lesław: Wady stalowej konstrukcji dachu zmodernizowanej hali przemysłowej. Wydawnictwo Uczelniane Politechniki Szczecińskiej, Szczecin 2011. XXV Konferencja Naukowo-Techniczna "Awarie Budowlane 2011". 
[11] PN-EN-1993-1-1:2006 Projektowanie konstrukcji stalowych, Część 1-1: Reguły ogólne i reguły dla budynków. PKN, Warszawa 2006.

[12] PN-EN-1090-2:2012 Wykonanie konstrukcji stalowych i aluminiowych, Część 2: Wymagania techniczne dotyczące konstrukcji stalowych. PKN, Warszawa 2012.

[13] Piątkowski Michał: Zwichrzenie sprężyste kratownicy z imperfekcjami. Materiały Budowlane, 8/2016:82-83.

[14] Shabnam Shayan, Kim Jr Rasmussen, Hao Zhang: On the modeling of initial geometric imperfections and residual stress of steel frames. Research report R935. Sydney 2012, School of Civil Engineering, The University of Sydney.

[15] Smak Milan., Straka Bohumil.: Geometrical and structural imperfections of steel member system. Procedia Engineering, 40/2012:434-439.

\section{METHODS FOR TAKING INTO ACCOUNT GEOMETRICAL IMPERFECTIONS IN STEEL TRUSS}

\section{S u m m a r y}

Current normative guidelines and research suggest that the design of complicated structures, especially frame systems, should take into account the influence of geometric imperfections. In case of trusses, imperfections can occur independently of each chord, which leads to a large variety of possible imperfect configurations. In this paper the author presents a different methods of taking in to account geometric imperfections, known from frame analysis, and the possibility of using them in the case of trusses. An extensive numerical analysis of a certain truss model was made to compare the presented methods and the effect of simultaneous transverse geometrical imperfections of both chords on the limit load of the truss. Out-of-straightness imperfections were considered throughout the entire length of the chord as well as between the points of the rigid side support. Based on the obtained results, the author developed equilibrium paths of the compressed chord. Described and used in the numerical analysis, methods of taking into account imperfections were evaluated in terms of labor intensity and their applicability in truss systems.

Keywords: imperfect model; trusses; analysis methods; limit load 